\title{
COMPACTION BEHAVIOUR OF LATERITIC SOIL MODIFIED WITH CEMENT AND RICE HUSK ASH FOR ROAD CONSTRUCTION
}

\author{
A. Idris ${ }^{1}$, A. Y. Abdulfatah ${ }^{2, *}$, S. S. Ahmad ${ }^{3}$ and A. A. Bashir ${ }^{4}$ \\ $\mathbf{1 , 2 , 3 , 4}$, Department of Civil Engineering, BAyero University, KANo, KANo StATE, NIGERIA \\ E-mail addresses: ${ }^{1}$ aidris.civ@buk.edu.ng, ${ }^{2}$ ayabdulfatah.civ@buk.edu.ng \\ 3ssa0900471@buk.edu.ng, 4 aab0900499@buk.edu.ng
}

\begin{abstract}
This study is an investigation into the possibility of using rice husk ash blended with cement (CRHA) in the modification of the basic engineering properties of a marginal lateritic soil with the aim of qualifying the soil for use in the construction of roads. In the study, the properties of the natural soil sample such as bearing strength (measured in California Bearing Ratio: CBR), compaction behaviour as well as other consistency parameters were evaluated. The same properties were also evaluated for the soil samples modified with C-RHA. The findings of the study show that an increase in values of the C-RHA results a decrease in plasticity. An improvement in the CBR was observed with increasing value of the RHA at specified cement contents with peak values at $5 \%$ cement and $10 \%$ RHA. This indicates the potential of using 7.5-10\% RHA admixed with 5\% cement contents for laterite soil stabilization for use as a sub-grade soil for road construction.
\end{abstract}

Keywords: Cement, Compaction behaviour, Lateritic soil, Rice husk ash, Soil stabilization, Road construction

\section{INTRODUCTION}

In Nigeria, just as in other subtropics and tropic countries, laterites are highly employed in several construction projects [1]. This is due to the availability of the lateritic soils as Nigeria lies on an uplifted land mass that is made up of basement sediments. Consequently, laterites are found in abundance and in relatively good quality for engineering construction work [2]. Lateritic soils are used widely in almost all transportation and highway construction projects. The laterites contribute to the economy of the regions and their scope is very wide including civil engineering projects [2]. Laterite is usually a surface formation in wet and relatively hot tropical regions and is usually found to be enriched in aluminum and iron. It is normally developed by long lasting as well as intensive weathering of the parent rock underneath. Many lateritic soils for road construction are found to fall within the A-1, A- 6 and A-7 groups of the American Association of State Highway and Transportation Officials (AASHTO) soil classification [3]. Also an important feature of the AASHTO classification is the group index which is based on the service performance of many soils [4]. It permits a more precise prediction of soil behaviour than is possible by soil classification alone. It is actually a means of rating the value of a soil as a sub-grade material within its group. The group index is a function of the percentage of soil passing B.S No 200 sieve and the Atterberg limits. As the group index increases for a particular group, the poorer or less satisfactory is the material for road construction. There are instances where the engineering properties of the soil are not up to standard, in such cases different materials with different properties may be employed in order to improve the desired soil properties to meet the requirements of the proposed construction works. The search for alternative binders or pozzolanic materials is attracting research attention in order to reduce the cost of road construction for a sustainable national development. In many developing countries, particularly Nigeria, there is a need to research more into the potential of laterite soil as a reliable and durable construction material as it is locally available and has been one of the major building and

\footnotetext{
* Corresponding author, tel: +234-806-603- 1086
} 
road construction materials for a long time. Any treatment applied to a given soil in order to improve or modify its engineering properties and reduce its vulnerability to water can be regarded as soil modification. If the treated soil is able to withstand the stresses imposed on it by traffic under all weather conditions without deformation, then it is generally regarded as stable and it can be qualified for use based on relevant requirements of the construction standards. The treatment of the soil to achieve a desired quality can be applied to a soil in situ or after the soil has been removed and placed in a pavement or embankment $[5,6]$. Over time, industrially manufactured lime and ordinary cement are the two main materials known to have a significant influence on the behaviour of lateritic soils. However, over the course of time, these materials have significantly increased in price and because of the over-dependence on these industrially manufactured products in soil stabilization, the cost of construction of stabilized rural roads has gone higher. Cement has also been reported to produce large amounts of Carbon dioxide $\left(\mathrm{CO}_{2}\right)$ that affects the environment and hence replacing a proportion of the cement by a secondary pozzolana like RHA will reduce the negative environmental impact of the stabilization process [7]. Hence the need for the use of agricultural wastes such as Rice Husk and its Ash (RHA), which is readily available and which has become even an environmental issue, will considerably reduce the cost of construction and will subsequently reduce the environmental hazard it may cause [8]. Thus, partially replacing the quantity of the industrially manufactured agents in soil modification with alternative pozzalan materials such as RHA will reduce the impact of the stabilization process (production of $\mathrm{CO} 2$ from cement) on the environment.

\subsection{Rice Husk Ash}

Rice husk is a normal by-product obtained by milling raw rice. The world rice production was 758.8 million tonnes in 2017 [9]. It was estimated that in 2017 more than $\mathbf{2 0 0}$ million tons of rice husk was generated in the world [9]. In Nigeria alone, the quantity of rice produced in 2017 was 5.8 million tonnes that is 5.5\% higher than the production of 2015 [10], giving rise to about 1.624 million tonnes of rice husk at the rate of $0.28 \mathrm{~kg}$ per $1.0 \mathrm{~kg}$ of rice [9]. This production is expected to increase rapidly as Nigeria now focused more on agriculture as oil revenue continues to dwindle. The disposal of agricultural wastes such as RHA has a potential negative impact on the environment as such it is important to make these wastes eco-friendly by using them as stabilizers in order to improve soil strength. The use of rice husk ash has recently been generating a lot of interest in the Nigerian construction industry. Rice husk ash (RHA) is a by-product obtained when the rice husk is burned. The rice husk itself is usually obtained as the byproduct of the rice-milling industry. About $28 \%$ by weight of the raw rice grain is rice husk [9]. Reference [11] reported on the production of high purity Armorphous Silica from Rice Husk while [12] reported on high purity nano silica powder from the rice husk. Burning the rice husk at a specified temperature transforms $15-20 \%$ of the rice husk in to rice husk ash (RHA) [8]. A lot of research on stabilizing lateritic soil using RHA has been reported in the literature $[13,14$, and 15] and more is needed, especially, in mixing RHA with the conventional binders such as cement in which the influence of RHA on some soils with improvement in their engineering properties can be studied. The use of other locally produced additives including RHA, in the stabilization of lateritic and other soil types, has also been reported [16]. Table 1 shows the chemical composition of RHA as reported in the literature as discussed above [17].

\section{Table 1: Chemical composition of RHA}

\begin{tabular}{lc}
\hline Properties & Chemical composition \\
\hline Silica $\left(\mathrm{SiO}_{2}\right)$ & $95.41 \%$ \\
Alumina $\left(\mathrm{Al}_{2} \mathrm{O}_{3}\right)$ & $0.00 \%$ \\
Iron oxide $\left(\mathrm{Fe}_{2} \mathrm{O}_{3}\right)$ & $0.82 \%$ \\
Calcium oxide $(\mathrm{CaO})$ & $0.00 \%$ \\
Potash $\left(\mathrm{K}_{2} \mathrm{O}\right)$ & $1.65 \%$ \\
Magnesium $(\mathrm{MgO})$ & $1.24 \%$ \\
Sodium $(\mathrm{Na} 2 \mathrm{O})$ & $0.22 \%$ \\
Sulphur $\mathrm{SO} 3)$ & $0.07 \%$ \\
Loss in ignition & $0.00 \%$ \\
\hline
\end{tabular}

The rice husk ash as a pozzolanic waste with an alkali activated binder can be used as an alternative to cement [18]. The total contents of $\mathrm{SiO}_{2}+\mathrm{Al}_{2} \mathrm{O}_{3}+\mathrm{Fe}_{2} \mathrm{O}_{3}$ exceeding $70 \%$ is an indication of a Class $\mathrm{N}$ mineral admixture according to [19]. Although, some work have been carried out in the area of use of waste in soil improvement, there has been extensive research work on utilization of pozzolanic materials especially rice husk ash in Nigeria, hence, the need to conduct experiment in that direction. Therefore this study was aimed at evaluating the potential utilisation of RHA with cement in the improvement of lateritic soils. The study was conducted to find the optimum C-RHA content so 
as to achieve a balance between economy and effective performance of the stabilized lateritic soil. Table 2 shows the physical properties of RHA.

Research on the potential of using RHA reveals that some of its physical properties are responsible for its role in improving the material properties and durability of its composite. Some important physical properties are larger specific surface area, fine particle size, high silica content, moisture resistance and heat resistance [21].

With increasing importance of lateritic soils in the expansion of construction activities in tropical countries, there is a need for continuous investigation into the use of wastes and pozzolanas to supplement often insufficient or very expensive available binding materials such as bitumen, cement and lime. It is hoped that the study will contribute to the use of RHA as supplement and close substitute for these binding materials. The study therefore, focused on determining the effect of rice husk ash blended with cement on the engineering properties of lateritic soil. It also aimed at quantifying the soil for use in the construction of roads.

\section{MATERIALS AND METHOD}

The sample of the soil used in this study was obtained through disturbed sampling at a location within the male students' residential area of the Bayero
University Kano New Campus, Nigeria. The sample was collected at a depth of $1.5 \mathrm{~m}$. Figure 1 shows the coordinates of the sampling location. Table 3 shows some geotechnical properties of the soil sample. The rice husk ash used in the study was obtained from rice millers in the neighborhood of Tarauni Local Government Area of Kano in Nigeria. The rice husk was collected, air-dried and burnt under atmospheric conditions (open burning). The collection of the rice husk ash was in sacks and transported to the testing laboratory. The ash was passed through BS 200 sieve $(75 \mu \mathrm{m})$ to meet the requirements of ASTM Class $\mathrm{F}$ pozzolanas (ASTM C618-78). The natural soil sample was air-dried and crushed to pass through BS sieve No.4 (4.67 $\mu \mathrm{m})$. Higher percentages of RHA alone were used by some researchers; $5,10,15$ and $20 \%$ by [22] and 10, 20, 30 and $40 \%$ by [21]. The two studies reported improved soil properties; however, there was a reduction in maximum dry density (MDD) and an increase in optimum moisture content (OMC). This study therefore, choose to use lower percentages of $0 \%, 2.5 \%, 5 \%, 7.5 \%$ and $10 \%$ of the rice husk ash with cement in order to study the changes in MDD and OMC. The chosen percentages of RHA were mixed with $0 \%, 5 \%, 10 \%$ and $15 \%$ cement by weight of dry soil.

Table 2: Physical properties of RHA

\begin{tabular}{cccccc}
\hline Specific gravity & Bulk density & Colour & Odour & Particle size & Appearance \\
\hline $2.05-2.3$ & $1.68 \mathrm{~g} / \mathrm{cm}^{3}$ & Grey & Odourless & 25 microns & Very fore \\
\hline \multicolumn{5}{c}{ Source: Reference [20] }
\end{tabular}

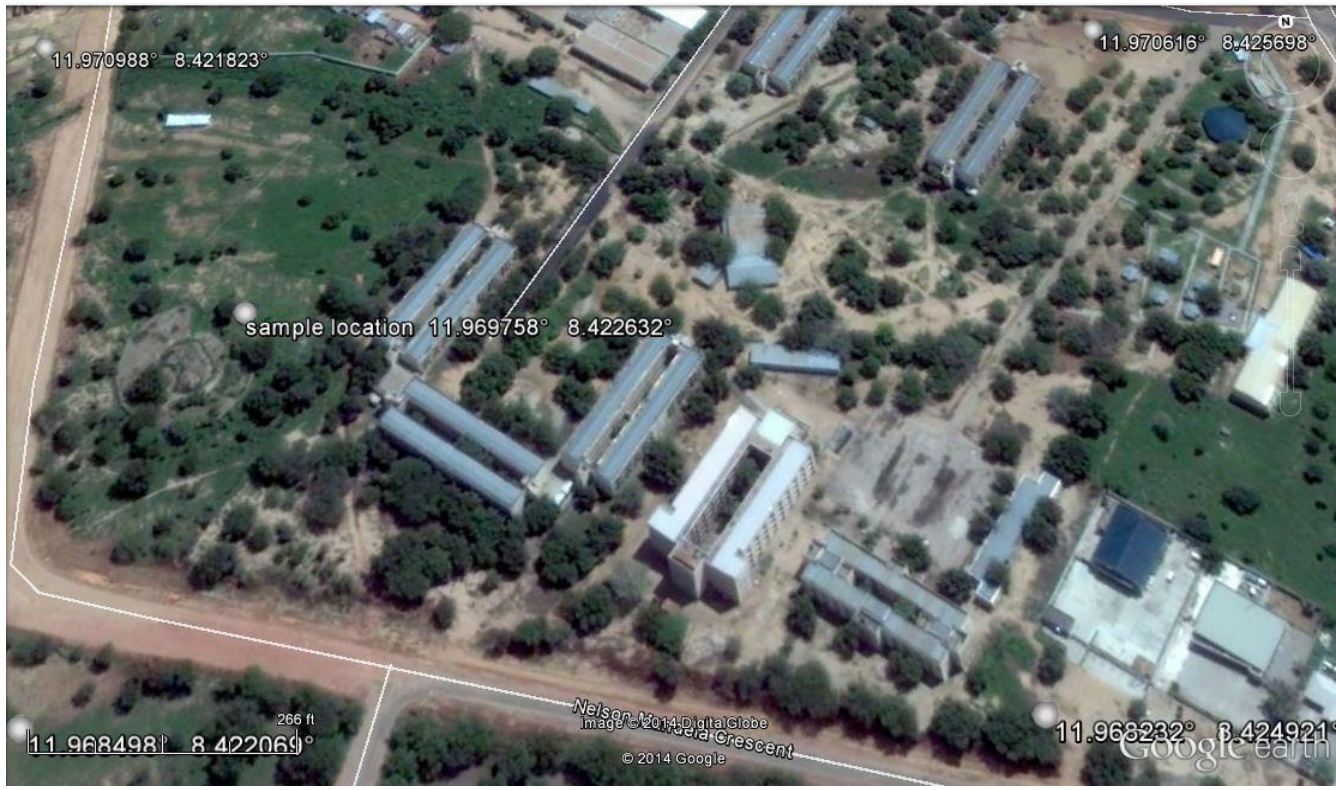

Figure 1: Soil sampling site 
The following tests were conducted: Atterberg limits, Compaction characteristics; maximum dry density (mdd) and optimum moisture content (omc), California Bearing Ratio (CBR). All tests were carried out in accordance with the specifications given in BS 1377 (1990).

\section{RESULTS AND DISCUSSION}

The results of laboratory tests on the identification of basic engineering properties of the natural soil are presented in Table 3. The soil is classified as A-7-5 based on the guidelines in [4]; having $17.29 \%$ gravel, $10.36 \%$ sand and $72.33 \%$ fines with a group index of 2. Hence the soil falls just below the standard recommendation for direct use for most construction works. Thus the soil is marginal in its strength with respect to road construction requirements. This inadequacy for use as pavement layer material is also reflected when reference is made to the Nigerian General Specifications [23] for road construction and therefore requires treatment in order to qualify its properties for that purpose.

\subsection{Atterberg Limits}

The results of the laboratory tests with $5 \%$ cement and varying RHA contents are shown in Figure 2. The results for 0,10 and $15 \%$ of cement were of the same pattern as Figure 2. The results show a general trend of a decrease in liquid limit values at all C-RHA combinations which may be due to the RHA pozzolanic reaction with the cement from compounds possessing cementitous properties. The lowest liquid limit recorded was $18.85 \%$ at $7.50 \%$ RHA and $15.00 \%$ cement content.

The plastic limit of the soil after addition of C-RHA increased as the C-RHA content was increased. The variation in plastic limit at $5 \%$ cement can be seen with values decreasing from 19.00 to $18.25 \%$. The value then increased to 19.00 and $21.35 \%$ at 7.5 and $10 \%$ RHA respectively.

The plastic limit of the lateritic soil sample increased with increasing cement and RHA contents. The possible explanation for this was that the increase in cement and RHA aided flocculation and aggregation in the fine particles of the sample as such more water was required for hydration which increased the effective grain size due to agglomeration of the clay particles.

A common specification for base course requires that the plasticity index shall not exceed $6 \%$. When compared with the conventional specifications in [23], most values recorded for the plasticity index are suitable for use as base course material but $5 \%$ cement and $10 \%$ RHA as shown in Figure 2 may be a better choice.

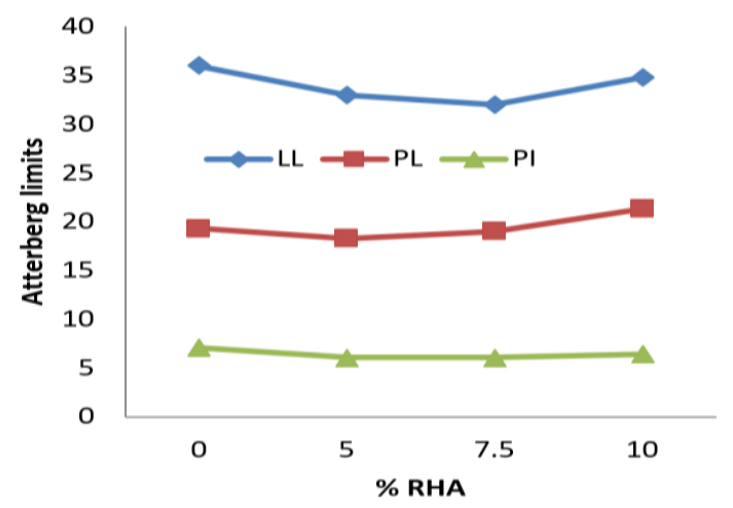

Figure 2: Atterberg limits at 5\% cement content

Table 3: Basic geotechnical properties of the soil sample

\begin{tabular}{lc}
\hline Liquid limit (\%) & 36.00 \\
Plastic limit (\%) & 19.30 \\
Plasticity index (\%) & 16.70 \\
Linear shrinkage (\%) & 7.10 \\
Specific gravity & 2.72 \\
Optimum moisture content (\%) & 9.30 \\
Maximum dry density $\left(\mathrm{g} / \mathrm{cm}^{3}\right)$ & 1.87 \\
CBR (\%) & 5.13 \\
AASHTO class & A-7-5 \\
Colour & Reddish brown \\
\hline
\end{tabular}

$\mathrm{LL}$ is the liquid limit, PL is the plastic limit and PI is the plasticity index.

\subsection{Compaction Properties}

\subsubsection{Optimum Moisture Content (OMC)}

An average compactive effort of West African Standard was used. It is shown in this paper that the trend in the change in values of OMC when RHA content was increased for each of the various cement contents has been relatively the same as can be seen in Figure 3. There was an increase in OMC with increasing RHA content for each of the cement contents. This may be due to the addition of C-RHA which may cause a decrease in the quantity of free silt and clay contents in the presence of water and thus resulting in the formation of coarser materials with larger surface. Hence it can be seen therefore, that more water was needed in order to compact the soil and C-RHA mixtures. The increase in OMC was as a result of the pozzolanic action of RHA and the soil that required 
more water for the reaction to complete. The decrease in OMC could be attributed to the absorption capacity of RHA due to its porous nature [24].

\subsubsection{Maximum Dry Density (MDD)}

This is the measure of densification attained by the application of compaction effort on the solid mass. Higher MDD values signify higher strength of the soil mass. The detailed results for the soil-cement and RHA combination at varying percentage are illustrated in Figure 4. The maximum dry density for the unstabilized soil sample was $1.87 \mathrm{~g} / \mathrm{cm}^{3}$. The maximum dry density generally decreased with increasing cement content to a value of $1.84 \mathrm{~g} / \mathrm{cm}^{3}$ at $10 \%$ cement. Also with the soil-RHA mixtures at $0 \%$ cement, the maximum dry density decreased down to $1.72 \mathrm{~g} / \mathrm{cm}^{3}$ at 7.5\% RHA above which it started to increase. From the curve, the decrease in values of MDD can be related to the replacement of soil by C-RHA in the mixture. The MDD decreased significantly to $1.54 \mathrm{~g} / \mathrm{cm}^{3}$ at $5 \%$ and $10 \%$ respectively. The decrease in the values of MDD can be attributed to the cationic exchange of cement which induces agglomeration and flocculation of the clay particles. This can also be attributed to reduction in specific gravity of the rice husk ash reported as 2.05 -2.30 [20] which is lower than that of the natural soil sample, determined as 2.72; therefore the lighter particles fill the voids of the flocculated soil matrix to give a less dense matrix.

\subsection{California Bearing Ratio (CBR)}

California Bearing Ratio (CBR) which is an indicator of compacted soil strength and bearing capacity is widely used in the design of base and sub-base material for embankment and pavement constructions. In the laboratory, CBR is one of the common tests used to evaluate the strength of stabilized soils. There was an increase in the CBR values at 5 and $10 \%$ cement with all values of RHA; however, the maximum CBR value is at $7.5 \%$ RHA. The values then decreased at $15 \%$ cement content. This may be attributed to the formation of cementitous compounds in the soil as a result of the reaction between the C-RHA and chemical compounds such as calcium hydroxide $(\mathrm{CaOH})$ present in the soil. On the other hand, the decrease in CBR values at RHA contents of more than $7.5 \%$ may be due to the extra RHA in the soil that could not react and consequently occupied the remaining void spaces in the sample. This had reduced the bond in the soil mixture. This conforms to the findings of $[6,15]$ that cement and RHA show significant effect on lateritic soil by increasing its CBR value.

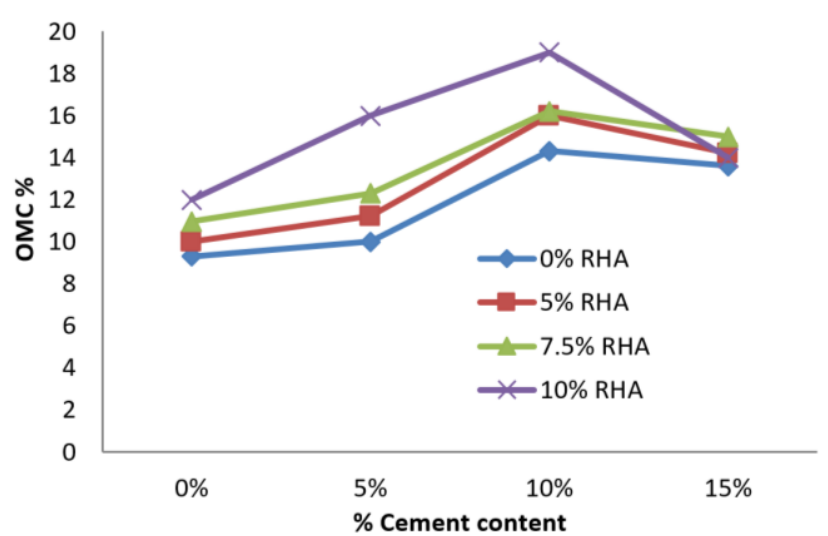

Figure 3: Variation of OMC with cement and RHA content

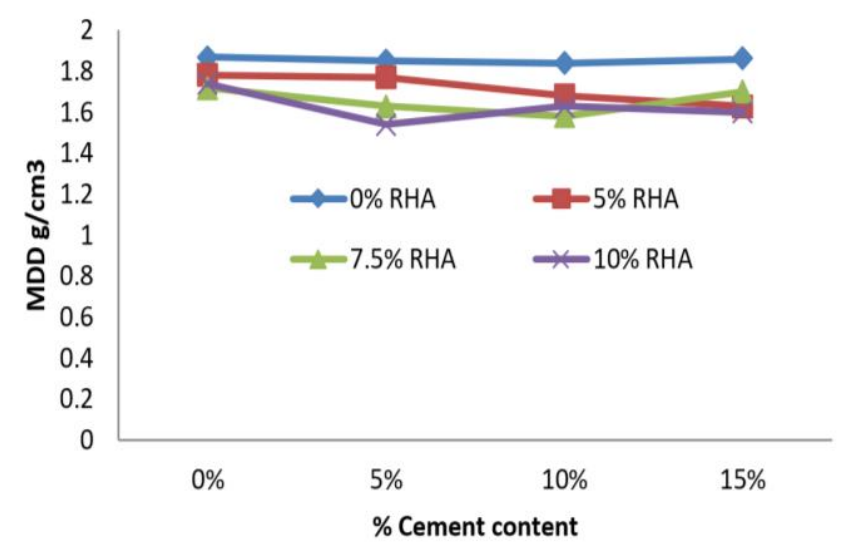

Figure 4: Variation of MDD with cement and RHA content

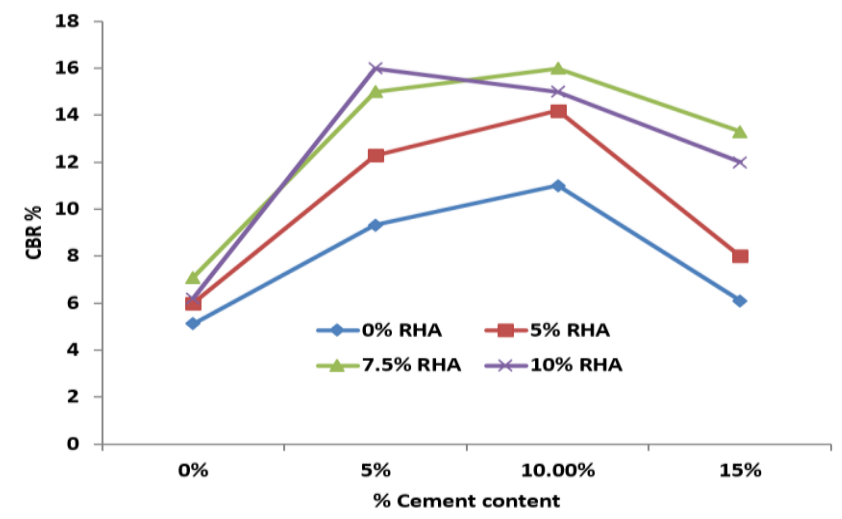

Figure 5: Variations in CBR with Cement and RHA contents

\section{CONCLUSIONS}

From the results obtained as presented in the previous section, it can be concluded that there were improvements indicated by the reduction of the liquid limit values to the lowest value of $18.85 \%$ obtained at $15 \%$ cement and $7.5 \%$ RHA. Plastic limit also reduced with an increase in the cement and RHA contents, 
while the plasticity index reduced considerably. The compaction of the natural soil sample exhibited a higher maximum dry density. The addition of cement and RHA showed a tremendous decrease in the MDD while the optimum moisture content increased with an increase in the cement-RHA contents. In general, it was found out that with an increase in RHA, MDD decreased and $\mathrm{OMC}$ increased. These unusual trends of the MDD and OMC were corroborated by [21] and [22]. The study also indicated a significant increase in CBR values when C-RHA was added as compared with the CBR values of the natural soil. The paper therefore concludes with a recommendation of addition of $5 \%$ cement and $10 \%$ RHA for an effective use in road subbase construction.

\section{REFERENCES}

[1] Okoyeh, E.I., Ejezie, O.E., Ezeh, H.N. and Okeke, H.C. "Evaluation of Ihiala Laterites for use as subgrade material in Road Construction", Journal of Geography, Environment and Earth Science International, Vol. 12 (3), pp. 1-9, 2017.

[2] Lemougna, P.N., Chinjemelo, U.F., Kamseu, E. and Tchamba, A.B. "Laterite Based Stabilized Products for Sustainable Building Applications in Tropical Countries: Review of Prospects for the case of Cameroon" Sustainability, Vol. 3(11), pp. 293-305, 2011.

[3] Kamtchueng, B.T., Onana, V.L., Fanton, W.Y., Ueda, A., Ntouala, R.F.D and Wongolo, M.H.D. "Geotechnical, Chemical and Mineralogical Evaluation of Lateritic Soils in Humid Tropical Areas (Mfou, Central Cameroon): Implications for Road Construction" International Journal of GeoEngineering, Vol. 6(11), 2015.

[4] American Association of State Highway and Transportation Officials (AASHTO) Guide for Design of Pavement Structures, Vol. 1, 1993.

[5] Abu-Farsakh, M. Y., Alshibli, K., Nazzal, M., \& Seyman, E. Assessment of in-situ test technology for construction control of base courses and embankments. Report No, FHWA/LA, 4, 385, 2004.

[6] Kisunge, J. Road Construction Materials: Basic Knowledge and Test Procedures, 2012.

[7] Devi, K.S., Lakshmi, V.V. and Alakanandana, A., İmpact of Cement Industry on Environment-An
Overview" Asia Pacific Journal of Research, Vol. 1 (57), pp. 156-160, 2017.

[8] Glushankova, I., Ketav, A., Krasnovskikh, M., Rudakova, L. and Vaisman, I. "Rice Hulls as a Renewable Complex Material Resource" Resources, 7 (31), 2018.

[9] Lokare, K.S. "Rising from the Ashes: Renewable Silica from Rice Husk Ash"www.biofuelsdigest.com/bdigest/2017/09/0 6/rising-from-the-ashes-renewable-silica-fromrice-husk-ash/ Accessed on 25th May 2019.

[10] Goronyo, A. "Rice Production in Nigeria increases to $5.8 \mathrm{~m}$ tonnes in 2017-RIFAN" Punch Newspaper Nigeria, May 17, 2017.

[11] Bakar, R.A., Yahaya, R. and Gan, S.N. "Production of High Purity Amorphous Silica from Rice Husk", Procedia Chemistry, 19, pp. 189-195, 2016.

[12] Yuvakkumar, R, Elango, V., Rajendran, V. and Kannan, N. "High Purity Nano Silica Powder from Rice Husk using a simple Chemical Method", Journal of Experimental Nanoscience, 9, pp. 272281, 2014.

[13] Usman, A.M., Raji, A. and Waziri, N.H., "Characterization of Girei Rice Husk Ash for Silica Potential"IOSR-Journal of Environmental Science, Toxicology and Food Technology, Vol. 8 (1), pp. 68-71. 2014.

[14] Tsado, T.Y., Yewa, M., Yaman, S. and Yewa, F., "Comparative Analysis of Properties of some Artificial Pozzolana in Concrete" International Journal of Engineering and Technology, Vol. 4 (5), pp. 251-255, 2014.

[15] Okafor, F. O., \& Okonkwo, U. N. Effects of rice husk ash on some geotechnical properties of lateritic soil. Nigerian Journal of Technology, 28(1), 46-52, 2009.

[16] Behak, L., "Soil Stabilization with Rice Husk Ash", Rice Technology and Production, Amanullah and Shah Fahad, IntechOpen, DOI: 10.5772/66311, 2017, Accessed on $20^{\text {th }}$ May 2019.

[17] Abalaka, A.E. and Okoli, O.G., "Comparative Effects of Air and Water CURING ON Concrete Containing Optimum Rice Husk Ash Replacement", Journal of Emerging Trends in Engineering and Applied Sciences, Vol. 4(1), pp. 60-65, 2013. 
[18] Karim, R., Hossain, M., Khan, M.N.N, Zain, M.F.M, Jamil, M. and Lai, F.C. "On the utilization of Pozzolanic Wastes as an Alternative Resources of Cement", Materials, Vol. 7, pp. 7809-7827, 2014.

[19] ASTM C618-03, "Standard Specification for Coal Fly Ash and Raw or Calcined Natural Pozzolan for use in Concrete", 2003.

[20] Obam, O.S. and Iorliam, A.Y., "Engineering Properties of Clay-Rice Husk Ash Composite" Journal of Engineering and Applied Sciences, Vol. 3, pp. 38-44, 2011.

[21] Ewa, D., Akeke, G.A. and Okoi, D., Ïnfluence of Rice Husk Ash Source Variability on Road
Subgrade Properties", Nigerian Journal of Technology, Vol. 37(3), pp. 582-586, 2018.

[22] Noohu, N.K. and Chandrakaran, S., Ïnfluence of Rice Husk Ash on Geotechnical Properties of Soft Clay", Asian Journal of Engineering and Technology, Vol. 3 (4), 2015.

[23] General Specifications (Roads and Bridges), Government of the Federal Republic of Nigeria, Vol. II, Revised 1997.

[24] Sarkar, G., Isalam, R, and Alamgir, M., "Interpretations of Rice hush on Geotechnical Properties of Cohesive Soil", Global Journal of Research in Engineering, Civil and Structural Engineering, 12(2): pp.1-8, 2012. 